University of Nebraska - Lincoln

DigitalCommons@University of Nebraska - Lincoln

Snag Benchmarks and Treatment Options for Mixed-Pine Forest Restoration in Eastern Upper Michigan

\author{
R. Gregory Corace III \\ U.S. Fish and Wildlife Service, Greg_Corace@fws.gov \\ Anna T. Stout \\ U.S. Fish and Wildlife Service \\ P. Charles Goebel \\ Ohio State University, cgoebel@uidaho.edu \\ David M. Hix \\ Ohio State University
}

Follow this and additional works at: https://digitalcommons.unl.edu/usfwspubs

Corace, R. Gregory III; Stout, Anna T.; Goebel, P. Charles; and Hix, David M., "Snag Benchmarks and Treatment Options for Mixed-Pine Forest Restoration in Eastern Upper Michigan" (2012). US Fish \& Wildlife Publications. 321.

https://digitalcommons.unl.edu/usfwspubs/321

This Article is brought to you for free and open access by the US Fish \& Wildlife Service at DigitalCommons@University of Nebraska - Lincoln. It has been accepted for inclusion in US Fish \& Wildlife Publications by an authorized administrator of DigitalCommons@University of Nebraska - Lincoln. 


\title{
Snag Benchmarks and Treatment Options for Mixed-Pine Forest Restoration in Eastern Upper Michigan
}

\author{
R. Gregory Corace III, ${ }^{1,2}$ Anna T. Stout, ${ }^{1}$ P. Charles Goebel, ${ }^{3}$ and David M. Hix ${ }^{4}$
}

\begin{abstract}
Snags (dead-standing trees) are biological legacies that remain after disturbances in forests. We enhanced the ecological underpinnings of snag management within the context of mixed-pine forest restoration in the northern Lake States by quantifying characteristics of live trees and snags within eighty-five 500- $\mathrm{m}^{2}$ plots at Seney National Wildlife Refuge (NWR) in eastern Upper Michigan. Study plots represented reference conditions (i.e. no past harvesting, relatively unaltered fire regime) and altered (i.e. harvested, altered fire regime) conditions. We also compared three treatments for creating snags from live trees. Snags were found in $87 \%$ of the reference plots and $85 \%$ of the altered plots. The only snag variables that differed between plot types were mean snag basal area, which was greater in
\end{abstract}

altered plots (Student's $t$-test, $p=0.04$ ), and mean percent total basal area of snags (greater in reference plots, $p=0.06$ ). The composition of snags differed only in the 10- and 25-cm diameter classes (Multi-Response Permutation Procedure, $p<0.10$ ). The percentage of snags that developed into the most advanced decay class (DC) differed among treatments after 4 years $\left(\chi^{2}=16.49, p<0.01\right)$, with $26 \%$ of girdled trees, $3 \%$ of prescribed fire trees, and zero topped trees reaching DC5. Logistic regression illustrated that the influence of predictor variables on DC development varied by species and treatment. The findings from this study, past studies, and ongoing projects at Seney NWR are directly applicable to innovative management of snags in mixed-pine forests.

Key words: biological legacy, ecological forestry, fire, red pine, Seney National Wildlife Refuge, snag transition rates.

\section{Introduction}

Snags (i.e. dead-standing trees) are biological legacies that remain after disturbances in forests. Snags play an important role in regulating ecological processes (e.g. nutrient cycling, carbon sequestration), providing refugia for propagules and microbes, and functioning as habitat for flora and fauna (Harmon et al. 1986). Snags, especially in mature forests, also play an important role as global carbon sinks (Luyssaert et al. 2008) and have important roles in fire ecology and management (Stephens 2004). Not surprisingly, snag management is a cornerstone of contemporary ecological forestry (Seymour \& Hunter 1999; Franklin et al. 2007). However, substantial variation exists in snag abundance and development over time

${ }^{1}$ U.S. Fish and Wildlife Service, Seney National Wildlife Refuge, 1674 Refuge Entrance Road, Seney, MI 49883, U.S.A.

${ }^{2}$ Address correspondence to R. G. Corace, email Greg_Corace@fws.gov

${ }^{3}$ The Ohio State University, School of Environment and Natural Resources, Ohio Agricultural Research and Development Center, 1680 Madison Avenue, Wooster, OH 44691, U.S.A

${ }^{4}$ The Ohio State University, School of Environment and Natural Resources, 2021 Coffey Road, Columbus, OH 43210, U.S.A.

Published 2012. This article is a U.S. Government work and is in the public domain in the USA.

doi: 10.1111/j.1526-100X.2012.00929.x

and among forest types (Harmon et al. 1986; Fridman \& Walheim 2000) such that snag management guidelines must be geographically and forest type-specific.

Changes in land use have been implicated in the homogenization of forest composition and structure and the decline of fire-dependent ecosystems in the northern Lake States. Across many ownership types, fire-sensitive deciduous tree species have displaced fire-dependent coniferous species (Corace et al. 2012). One ecosystem type that has experienced a significant reduction in dominance is mixed-pine forests of red pine (Pinus resinosa Ait.) and eastern white pine (P. strobus L.). These forests were common during pre-EuroAmerican times, with 3.9 million ha dominated by mixed-pine or similar forest ecosystem types (Frelich 2002). Today many sites have been converted to monotypic, artificially regenerated pine plantations and turn-of-the-century logging, wildfires outside the natural range of variation, and fire suppression have altered the structure and composition of the remaining naturally regenerated, second-growth stands (Stearns \& Likens 2002; Drobyshev et al. 2008b).

Efforts to restore mixed-pine forests have begun because of the multiple ecosystem services they provide and associated changes in some federal policy (Meretsky et al. 2006). Restoration at Seney National Wildlife Refuge (NWR; Corace 
et al. 2009) has been guided by studies of old-growth mixed-pine stands that serve as restoration benchmarks. The existence of these stands has allowed the reconstruction of fire regimes using dendrochronology (Drobyshev et al. 2008a) and the quantification of relationships among forest structure and composition variables along a disturbance gradient (Drobyshev et al. 2008b). Studies are also underway that examine recruitment of red pine and eastern white pine using variableretention harvesting systems.

Learning more about the differences between snag populations in reference and altered (non-reference) stands is critical for a holistic approach to conserving or restoring forests. For example, Fridman and Walheim (2000) were able to provide a more complete picture of the natural range of variability in snag abundance among managed coniferous forest types in Sweden. However, much of the North American literature regarding the general concept of snag management in fire-dependent ecosystems consists of studies from the Intermountain West and Pacific Northwest (Morrison \& Raphael 1993; Hutto 2006), ecosystems comprised of a different suite of species, growing on different landforms, and shaped by different disturbance regimes than are found in the northern Lake States. Throughout the northern Lake States, we know of only one study (Fraver \& Palik 2012) that characterized snags from reference mixed-pine stands. A more complete understanding of the natural range of variation of the structure of, and the specific management practices for, snag populations in firedependent forest ecosystems of the northern Lake States is, therefore, needed.

The goal of this study is to enhance the ecological underpinnings of snag management for mixed-pine forest restoration and ecologically based management of second-growth pine stands (natural and artificial). We use data from two separate, but related, projects to: (1) improve our understanding of the natural range of variation of snag characteristics and (2) provide the most appropriate recommendations for snag management. The objectives of this study are to: (1) describe the natural range of variation in characteristics of live trees and snags sampled in reference mixed-pine plots and compare these findings to formerly mixed-pine plots that have been altered from their historic conditions, but are still pinedominated and naturally regenerated; (2) examine relationships among these patterns and potential ecological drivers (e.g. density-dependence and fire); and (3) compare and contrast three treatments (girdling, prescribed fire, and topping) for creating snags from live trees. We hypothesize that the average abundance, density, and size of snags will all be greater within reference mixed-pine plots. We also hypothesize that snag decay class (DC) development will differ among treatments over time and among species, with shorter-lived tree species developing advanced DCs faster.

\section{Study Area}

This study was conducted at the 38,542-ha Seney NWR (N46.271594 ${ }^{\circ}$ W86.057078 ${ }^{\circ}$ ), Schoolcraft County, Michigan, U.S.A. (Fig. 1). Due to their inaccessibility within a mosaic of shrub and open wetlands, refuge records and related research (Drobyshev et al. 2008a, 2008b) indicate that areas sampled within the Seney Wilderness Area have never been harvested and represent some of the best examples of reference, oldgrowth mixed-pine ecosystems in the northern Lake States. Most of the remaining plots were established on nearby glacial outwash channels that were altered from their preEuroAmerican condition, first by turn-of-the-century logging (Drobyshev et al. 2008b; Rist 2008).

Seney NWR lies within the Seney Sand Lake Plain (Albert 1995). This ecoregion is predominately forested and in mostly public ownership (Corace et al. 2012). Landforms of lacustrine origin characterize the area. The climate is influenced by its close proximity to the Great Lakes. The most common winds are from the southwest to northwest. Average daily humidity during spring and fall varies from 50 to $60 \%$. Temperature extremes range from approximately -43 to $37^{\circ} \mathrm{C}$. Average annual precipitation is $81 \mathrm{~cm}$ and average annual snowfall is $312 \mathrm{~cm}$. According to the habitat typing system of Burger and Kotar (2003), 58\% of the soil types would have mixed-pine forests as the dominant late-successional community type.

\section{Methods}

\section{Snag Management Benchmarks}

We used data from $8550 \mathrm{~m} \times 10 \mathrm{~m}\left(500 \mathrm{~m}^{2}\right)$ plots established as part of a fire-history study (Drobyshev et al. 2008a). The diameter at breast height $(\mathrm{dbh} ; 1.37 \mathrm{~m})$ of snags was measured as part of an inventory of all overstory trees $(>10 \mathrm{~cm} \mathrm{dbh})$, and included 38 reference and 47 altered plots. The fire regime of reference plots are considered relatively unaltered based on the reconstructions of Drobyshev et al. (2008a). Specifically, the fire-return intervals (FRI) in the Seney Wilderness Area were found to not increase over time as would be expected in areas undergoing fire suppression: for the pre-European period (1707-1859), the FRI was $32.7 \pm 19.2$ years, the FRI was $14.5 \pm 10.6$ years for the settlement period (1860-1935), and the FRI was $18.5 \pm 11.5$ years for the post-refuge establishment period (1936-2006). All plots were established on deep, sandy soils with similar successional trajectories, and differences in the present structure and composition are a result of past management activities and disturbance regimes, and not site capability per se.

Plot data were tested for normality using the Shapiro-Wilk test; one altered plot was removed because of extreme outliers. Data with non-normal distributions were transformed (natural $\log$ transformation for live tree and snag dbh; square root transformation for live tree and snag basal area $\left[\mathrm{m}^{2} / \mathrm{ha}\right]$, live tree density and snag density [stems/ha], percent snag basal area, and percent snag density) and then retested for normality. A two-sided Student's $t$-test for independent samples was used to compare data between reference and altered plots. All means shown are untransformed grand means for reference and altered plots. We used Multi-Response Permutation Procedure (MRPP) to test the hypothesis that snag composition (within diameter classes) was not different between reference and 


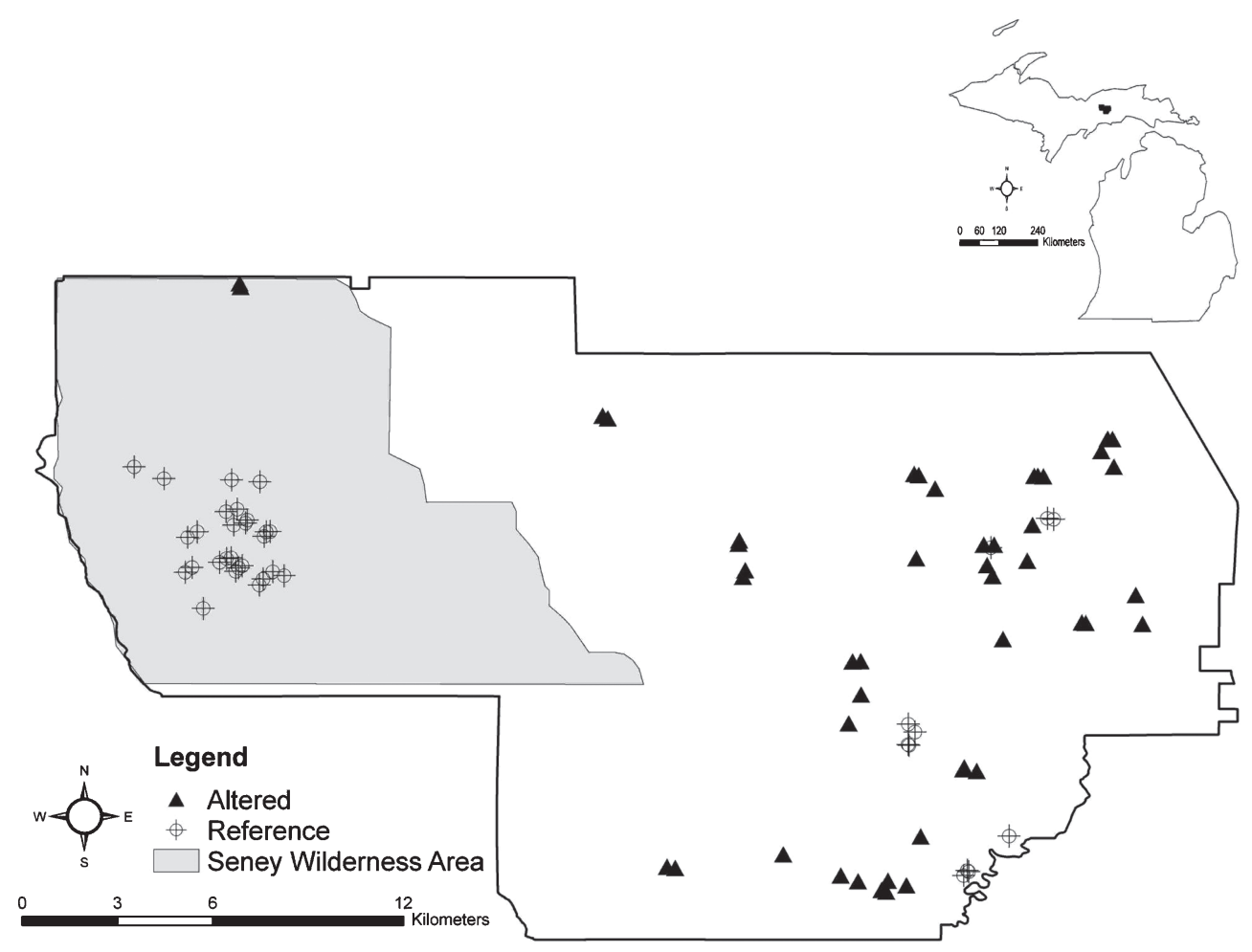

Figure 1. Distribution of reference (circles) and altered (triangles) plots at Seney National Wildlife Refuge, eastern Upper Michigan, U.S.A. Most reference plots were in the Seney Wilderness Area.

altered plots. MRPP is a nonparametric test and requires neither normally distributed data nor variance homogeneity (McCune \& Grace 2002). We used Sorenson's distance and a weighting factor, and made pairwise comparisons.

Years since last fire (YLF) was determined by dendrochronological methods (Drobyshev et al. 2008a). Briefly, fire-scarred live trees, stumps, and snags were sampled by "wedge sampling." Samples were mounted on wood and polished to allow recognition of annual rings and fire scars under a binocular microscope. All samples were cross-dated using a visual approach, which included skeleton plots and local chronologies. Linear regression was used to examine the relationship between density of trees and snags and between YLF and snag density.

\section{Snag Treatments}

We determined 4-year patterns in snag DC development across a pool of tree species for three different treatments: girdled, prescribed fire, and topped. Girdling was done as part of a restoration treatment in July and August 2007. We used regionally common logging equipment (i.e. machines that fell and then cut trees to a pre-determined length) to girdle live trees. A single operator girdled 107 trees by attaching onto the main stem with a "clam head" and raising and lowering the arm of the machine, stripping bark off the tree. All girdled trees were $>18 \mathrm{~cm} \mathrm{dbh}$, the approximate mean dbh of the pine-dominated stand before harvest. Snags were created from
Table 1. Snag decay classes.

\begin{tabular}{lc}
\hline Decay class & Characteristics \\
\hline DC1 & $\begin{array}{c}\text { Recently dead trees with intact tops and the majority } \\
\text { of fine branching present } \\
\text { Trees with loose bark, intact tops, most of the fine } \\
\text { branches }\end{array}$ \\
DC2 & $\begin{array}{c}\text { Trees with }<50 \% \text { of initial coarse branches and } \\
<50 \% \text { bark }\end{array}$ \\
DC3 & $\begin{array}{c}\text { Trees with broken tops, with few or no coarse } \\
\text { branches, }>6 \mathrm{~m} \text { in height } \\
\text { DC4 }\end{array}$ \\
DC5 & $\begin{array}{c}\text { coarse branches, }<6 \mathrm{~m} \text { in height. } \\
\end{array}$
\end{tabular}

15 red pine, 5 eastern white pine, 61 jack pine (Pinus banksiana Lamb.), and 26 aspen (Populus spp.). During the initial treatment, we recorded for each girdled tree: (1) species, (2) dbh, and (3) height (m). Because trees may protect one another from the influence of wind and thus reduce the breakage of snags, we also measured distance to the nearest tree $(\mathrm{m})$ and number of trees in 10-m radius. During subsequent visits in May to August between 2008 and 2011, we revisited each girdled tree to collect data on DC development as adapted from Hunter (1990) (Table 1).

The 4-year patterns in DC development for girdled trees were compared with a retrospective analysis of snags resulting from two other treatments in 2004: prescribed fire and topped (i.e. cutting off a tree stem approximately $3 \mathrm{~m}$ above the ground 
using the same mechanized logging equipment as above). Thirty prescribed fire trees were sampled (18 jack pine, 9 red pine, and 3 eastern white pine) and 31 topped trees ( 26 jack pine and 5 aspen) were sampled. A one-time assessment of DC development was measured for a random sample for both treatments in 2008. Because we only followed girdled trees during each of the 4 years and did not follow the trees in the other two treatments each year, we were only able to measure tree species-specific DC transition rates (proportion of snags that develop into different DCs over time) for girdled trees.

We used a chi-square test to ascertain whether there were differences in the percentage of snags reaching DC5 across the pool of treated trees in each treatment. We used ordinal logistic regression to examine the relationship of DC development after 4 years for girdled trees and for prescribed fire trees using tree $\mathrm{dbh}$, height, distance to nearest tree, and number of trees in 10-m radius as predictor variables and DC1-5 as response variables. The same was done for the topped trees, but without height as a predictor variable.

\section{Results}

\section{Snag Management Benchmarks}

Reference and altered plots were dominated by live stems of red pine, with a lesser component of eastern white pine and other tree species: jack pine, aspen, paper birch (Betula papyrifera Marsh.), red maple (Acer rubrum L.), red oak (Quercus rubra L.), black spruce (Picea mariana Mill.), and balsam fir (Abies balsamea Mill.). Red pine had the greatest mean $( \pm 1 \mathrm{SD})$ basal area $\left(33.8 \pm 13.1 \mathrm{~m}^{2} / \mathrm{ha}\right)$, the greatest mean density (564.2 \pm 266.0 stems/ha), and was the most frequently encountered live tree species in reference plots $(100 \%$ of plots).

Live stems of red pine were also found in $96 \%$ of the altered plots, and red pine was the dominant tree species within them: mean basal area $24.9 \pm 17.4 \mathrm{~m}^{2} / \mathrm{ha}$; mean density $482.6 \pm 391.3 \mathrm{stems} / \mathrm{ha}$. Although these same tree species were found in altered plots, live stems of jack pine were considerably more prevalent ( $67 \%$ of altered plots had jack pine), with a mean basal area and mean density of $6.1 \pm 7.7 \mathrm{~m}^{2} / \mathrm{ha}$ and $223.5 \pm 361.2$ stems/ha, respectively. The diameter class distributions of live trees in reference and altered plots were both "reverse-J" curves (Fig. 2). Unlike the reference plots, however, the number of live stems of the smallest size class in the altered plots was nearly twice the number of stems found in the next largest size class.

Snags were found in $72(85 \%)$ of the sampled plots: 33 of the reference plots $(87 \%)$ and 39 of the altered plots $(85 \%)$. The compositions and structures of snags were similar to those for live trees, with jack pine being more prevalent in the altered plots. Surprisingly, altered plots had a lower percentage of snags $(39 \%)$ in the smallest size class $(\leq 10 \mathrm{~cm})$ than reference plots $(47 \%)$. The diameter class distributions for snags in reference and altered plots were similar (Fig. 3). However, MRPP suggested that differences existed between

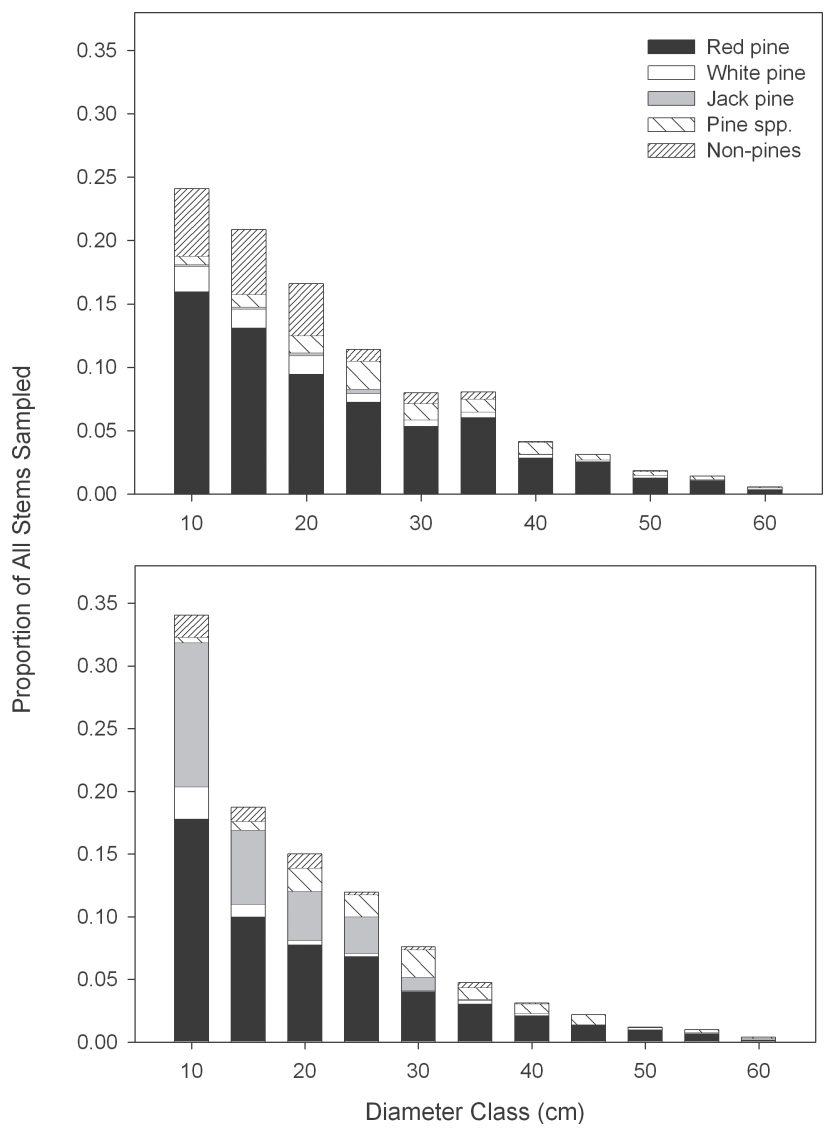

Figure 2. Diameter class distribution of live trees in reference (top) and altered (bottom) plots. "Non-pines" species are listed in the text.

snag composition of reference and altered plots in the 10$\mathrm{cm}(T=-1.58, A=0.02, p=0.08)$ and $25-\mathrm{cm}$ size classes ( $T=-1.69, A=0.53, p=0.07$ ) only.

Reference plots were on average dominated by larger live trees, with both mean dbh $(p=0.03)$ and mean density of live trees $>40 \mathrm{~cm}$ greater in these plots than altered plots $(p=0.02$; Table 2). However, few differences in snag structure were observed between reference and altered plots, with only basal area of snags and percent overall basal area contributed by snags greater in altered plots $(p=0.04$ and 0.06 , respectively; Table 2). Regressions relating basal area and density of live trees and basal area and density of snags in reference and altered plots, respectively, explained little of the observed variability $\left(R^{2}<0.05\right.$ in each), although greater variation was noted in each case for altered plots (Fig. 4). Similarly, the basal areas and densities of live trees and of snags were not closely related $\left(R^{2}<0.10\right.$ in each) with YLF, with substantial variability within plots shown in the data corresponding with the most recent large (>10,000 ha) wildfire, the 1976 Seney Fire (Fig. 5).

\section{Snag Treatments}

Four years after treatment, the percentage of treated trees among snag DC1-5 differed by treatment group: none of 


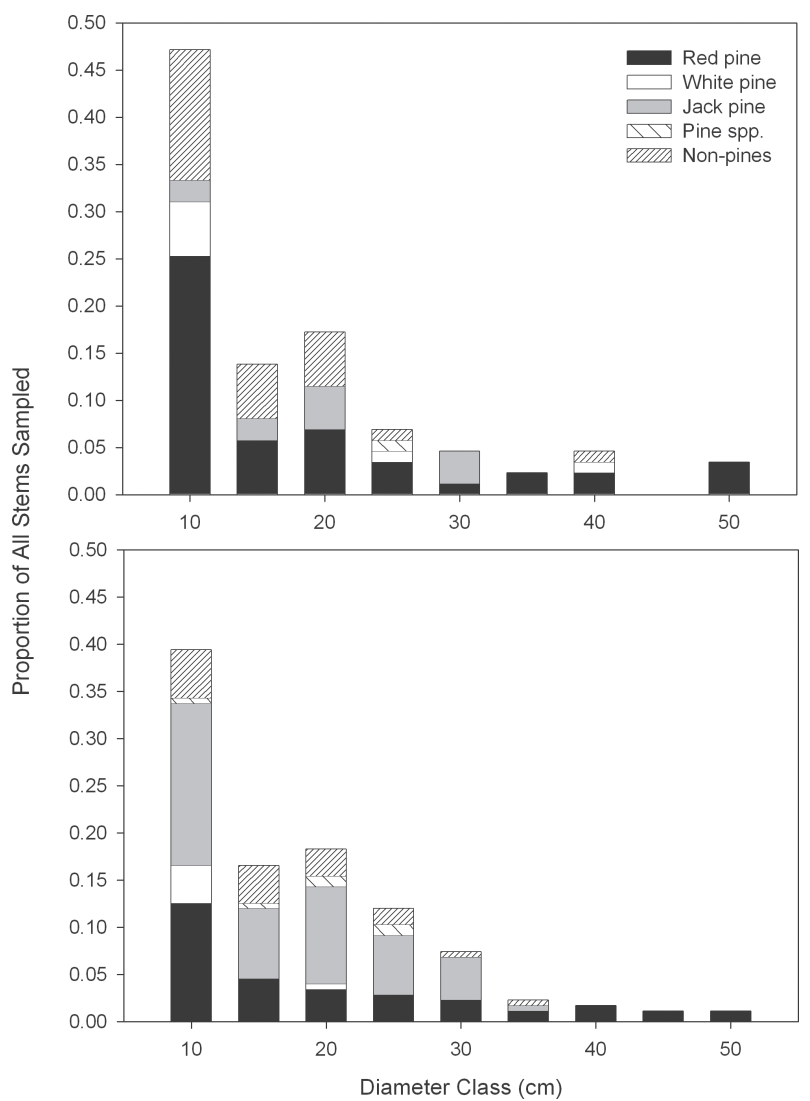

Figure 3. Diameter class distribution of snags in reference (top) and altered (bottom) plots. "Non-pines" species are listed in the text.

the topped snags were in DC1, while 3 and $5 \%$ were still in $\mathrm{DC} 1$ for the prescribed fire and girdled trees, respectively. The percentage of snags that developed to DC5 differed among treatments $\left(\chi^{2}=16.49, d f=2, p<0.01\right)$. None of the topped trees reached DC5, while $3 \%$ of the prescribed fire and $26 \%$ of the girdled trees did. Topped trees were found in DC2-4, while DC1-5 were represented in the prescribed fire and girdled trees; the modal DC for topped was DC2 and DC3 (tie, 45\%), DC3 $(43 \%)$ for prescribed fire, and DC4 (38\%) for girdled.

For the 4 years over which we followed DC development in girdled trees, species-specific patterns of DC transition rates were observed (Table 3). Jack pine developed a greater range of DCs than did aspen or red pine in the first year after treatment, while all species illustrated some ability to move across DCs over 4 years. Unlike jack pine and aspen that had $<5 \%$ of girdled snags in DC1 after 4 years, however, $31 \%$ or girdled red pine had not undergone further DC development. For all overall logistic regression models other than topped jack pine, at least one predictor variable influenced DC development (model likelihood ratio $<0.10$ ), but the influence of predictor variables varied by species and treatment. For instance, DC development in girdled aspen was most influenced by height, whereas size (dbh) and distance to nearest tree influenced DC development in girdled jack pine, with more mixed effects of variables in girdled red pine (Table 4).

\section{Discussion}

Our data did not support the hypothesis that snag attributes would, on average, be greater within reference plots than altered plots. This contrasts with past studies in Sweden that showed the average abundance and size of coniferous deadwood (a proportion of which includes snags) was lower in managed stands across forest types (Fridman \& Walheim 2000). Likewise, in red pine forests across the northern Lake States, Duvall and Grigal (1999) showed that timber harvesting had a negative impact on snag abundance. We suggest three possible explanations, supported by Rist (2008), for why our results differed and why we found seemingly less adverse

Table 2. Characteristics of live trees and snags in reference and altered plots.

\begin{tabular}{|c|c|c|c|c|}
\hline Variable & Reference $(\mathrm{n}=38)$ & Altered $(\mathrm{n}=46)$ & df & $\mathrm{t}(\mathrm{p})$ \\
\hline Total no. of snags & 87 & 175 & - & - \\
\hline Total no. of snags $>40 \mathrm{~cm} \mathrm{dbh}(\mathrm{cm})$ & 7 & 8 & - & - \\
\hline Total no. of live trees $>40 \mathrm{~cm}$ dbh $(\mathrm{cm})$ & 181 & 159 & - & - \\
\hline \multicolumn{5}{|l|}{ Mean $( \pm 1 \mathrm{SD}) \mathrm{dbh}(\mathrm{cm})$} \\
\hline Snags & $21.5(9.8)$ & $22.1(9.6)$ & 70 & $0.30(0.77)$ \\
\hline Snags & $45.8(35.1)$ & $76.1(77.8)$ & 82 & $1.49(0.14)$ \\
\hline Snags $>40 \mathrm{~cm} \mathrm{dbh}$ & $3.7(7.9)$ & $3.5(9.7)$ & 82 & $0.11(0.46)$ \\
\hline Live trees & $863.2(279.6)$ & $879.6(363.4)$ & 82 & $0.02(0.98)$ \\
\hline Live trees $>40 \mathrm{~cm} \mathrm{dbh}$ & $95.3(47.1)$ & $69.1(44.8)$ & 82 & $2.48(0.02)$ \\
\hline$\%$ Snags of total live trees & $6.1(5.7)$ & $10.6(13.4)$ & 82 & $1.41(0.16)$ \\
\hline \multicolumn{5}{|l|}{ Mean $\left( \pm 1\right.$ SD) basal area $\left(\mathrm{m}^{2} / \mathrm{ha}\right)$} \\
\hline
\end{tabular}



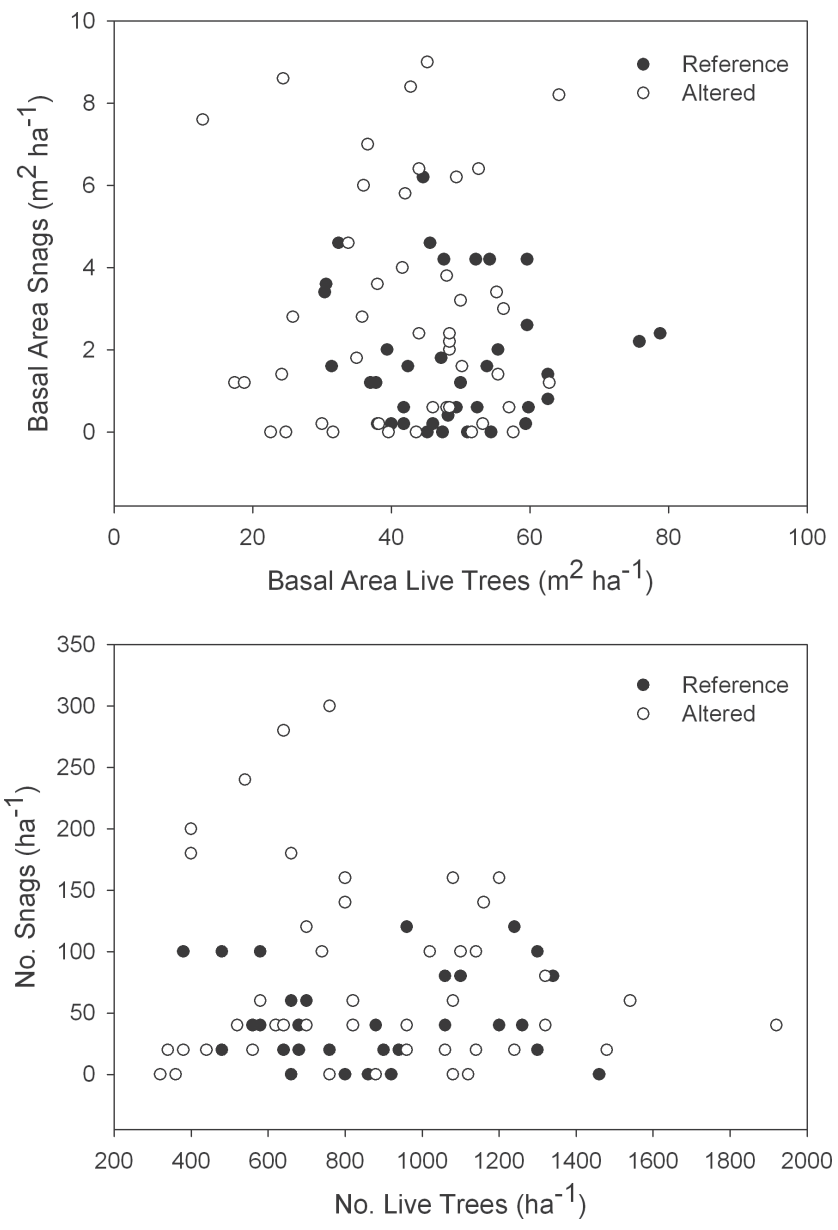

Figure 4. Relationship between basal area of live trees and the basal area of snags (top) and density of live trees and the density of snags (bottom) in reference and altered plots.

impacts on snag populations from past forest harvesting: (1) inventories indicated that jack pine was a substantial component of altered plots at the time of refuge establishment in 1935 and jack pine was a focus of past harvesting, (2) that enough time has occurred between disturbances (harvesting and/or fire) for snag populations to converge to patterns similar to reference plots, and (3) that refuge management has differed from more commercially driven enterprises and snags and older trees were more likely retained. Moreover, unlike other fire-dependent pine ecosystems (Stephens 2004) in which high variability was observed in snag attributes of reference stands, we observed considerably more variability in snag characteristics in altered plots rather than reference plots. These findings extend our present knowledge of snag patterns across forest ecosystem types (Harmon et al. 1986; Fridman \& Walheim 2000).

Unfortunately, we were not able to discern any clear relationships between snag abundance and density-dependent or disturbance-dependent mortality, leaving unanswered the difficult question of which factors are driving mortality in these forests. However, our findings of "reverse-J" diameter distributions of trees and snags does leave open the possibility that snags (especially jack pine snags) developed from competition and self-thinning, as suggested by studies in eastern boreal forests in Canada (Angers et al. 2010). Nonetheless, Franklin et al. (1987) indicated that a diverse array of potential abiotic and biotic contributors to tree death exists, including senescence and biotic stressors. Aakala et al. (2012) further suggest that although exogenous disturbances are often considered important factors in the dynamics of pine forests, background mortality may be just as important. More study is needed to understand the development of snags in both of our plot types over time.

Our data across three snag treatments support the hypothesis that DC development differs among treatments over time and among species, with shorter-lived tree species generally developing advanced DCs faster. Girdled trees did behave similarly to jack pines girdled by large equipment in Lower Michigan (Corace et al. 2010), and the variability observed in DC development among tree species has also been shown for snags developed under natural disturbances in unharvested forests of northwestern Quebec (Angers et al. 2010). However, whereas we show that jack pine had more variability in transition rates than most conspecifics, others have shown just the opposite, suggesting that DC development differs locally among tree species and forest type and supporting the general theory that species show individual responses to mortality (Angers et al. 2010). Whether or not DC patterns among our treatments emulates DC development under natural disturbances in mixed-pine forests requires more study.

Reference conditions are critical in that they can be used to quantify the natural range of variation that can guide forest conservation and restoration (Hansen et al. 1991). Our reference plots provide information that improves our understanding of snag patterns within the context of mixedpine forest conservation and restoration in the northern Lake States by providing a contrast to the work of Fraver and Palik (2012). Our reference plots were similar to their reference sites in Minnesota in that the overstory was red pine-dominated, with eastern white pine and other species less dominant. Our reference plots differed in that they had, on average, slightly greater basal area of live trees $\left(48.8 \mathrm{~m}^{2} / \mathrm{ha}\right)$ and slightly less basal area of snags $\left(1.8 \mathrm{~m}^{2} / \mathrm{ha}\right)$ than covered by the range of values from Minnesota (trees: range, $25.6-43.1 \mathrm{~m}^{2} / \mathrm{ha}$; snags: range, $2.7-14.2 \mathrm{~m}^{2} / \mathrm{ha}$ ). The density of snags on our reference plots (45.8 stems/ha) was within the range from Minnesota (24-140 stems/ha). Conversely, relative to unharvested jack pine-dominated stands in Canada which had 275-525 snags/ha and $4.9-7.9 \mathrm{~m}^{2} /$ ha (Angers et al. 2010), our mixed-pine plots were significantly lower in both metrics.

Although reference plots had more large live trees for development into future snags, our findings indicate that both plot types may now provide habitat for cavity-dependent wildlife species, e.g. black-backed woodpecker (Picoides arcticus Swainson). Youngman and Gayk (2011) found that nesting woodpeckers were in snags similar to those found in our plots. Moreover, the heights of nests in snags they studied suggest that many snags reaching DC5 may still be used by this 

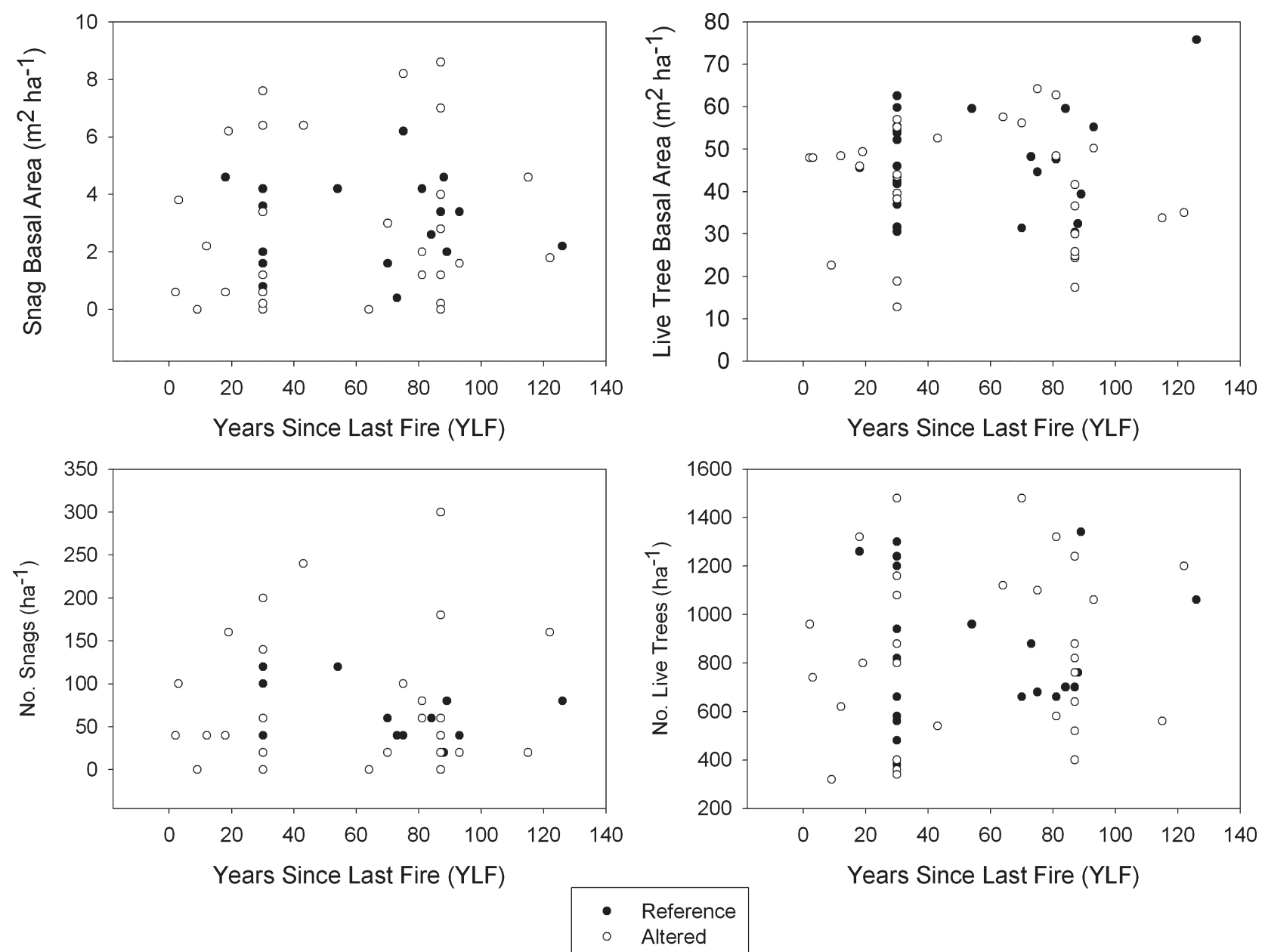

Figure 5. Relationship between years since last fire (YLF) and live tree and snag basal area and density in reference and altered plots.

Table 3. Snag transition rates for all girdled trees $(n=103)$ and for those girdled species with $>10$ individuals: aspen $(n=25)$, jack pine $(n=59)$, and red pine $(n=14)$.

\begin{tabular}{|c|c|c|c|c|c|c|}
\hline Species & 2011 Decay Class & \multicolumn{5}{|c|}{2008 Decay Class } \\
\hline \multirow[t]{4}{*}{ All } & 1 & 0.08 & & & & \\
\hline & 3 & 0.08 & 0.06 & 0 & & \\
\hline & 4 & 0.41 & 0.41 & 0 & 1.0 & \\
\hline & 5 & 0.15 & 0.29 & 0 & 0 & 1.0 \\
\hline \multirow{2}{*}{ Aspen } & 4 & 0.58 & 0.50 & 0 & 0 & \\
\hline & 5 & 0.16 & 0.50 & 0 & 0 & 0 \\
\hline \multirow[t]{4}{*}{ Jack pine } & 1 & 0.04 & & & & \\
\hline & 2 & 0.39 & 0.23 & & & \\
\hline & 3 & 0.09 & 0.08 & 0 & & \\
\hline & 4 & 0.26 & 0.42 & 0 & 1.0 & \\
\hline Red pine & 5 & 0.08 & 0 & 0 & 0 & 0 \\
\hline
\end{tabular}

Decay classes are described in Table 1. 
Table 4. Ordinal logistic regression analysis of decay class development (DC1 - 5) for three different treatments.

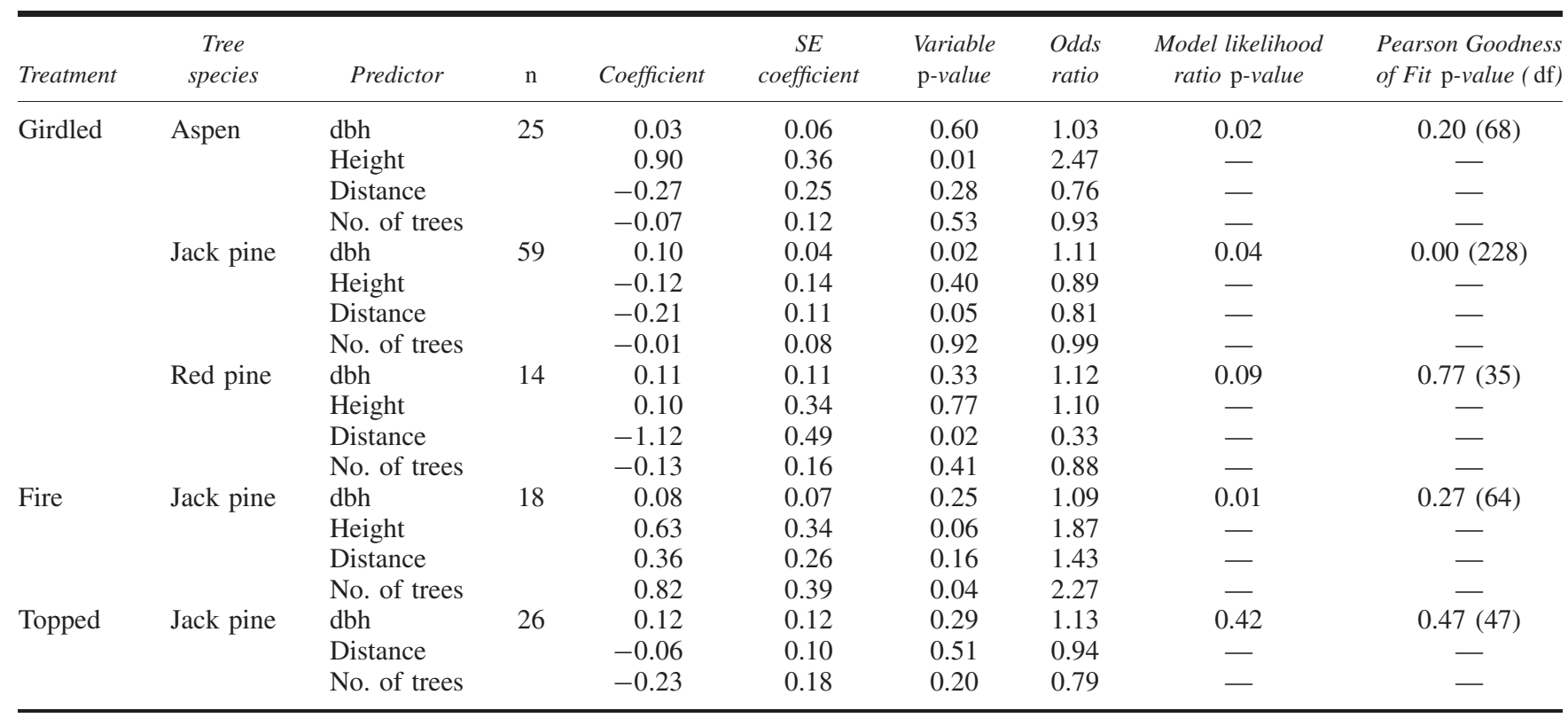

Predictor variables for girdled and prescribed fire trees were tree $\mathrm{dbh}(\mathrm{cm})$, height $(\mathrm{m})$, distance to nearest tree $(\mathrm{m})$, and number of trees in 10 - $\mathrm{m}$ radius; height was not used as a predictor variable for topped trees. Analysis was only conducted for tree species with sample size $>10$.

species. Recently burned sites, whether reference or altered, may provide these birds habitat. The abundance of jack pine trees and snags we found in altered plots also suggests that fire would likely behave quite differently in altered plots relative to the reference plots. For instance, with the higher density of jack pine in stands similar to the altered plots managers may expect prescribed fires to be more severe as jack pine is a notoriously poor self-pruner and this characteristic helps promote severe crown fire.

Considerable research has documented the value of emulating forest patterns that arise from natural disturbances. To provide more structural heterogeneity in simplified pine plantations and other altered, formerly mixed-pine stands, we suggest land managers consider the range of treatments we described to produce more varied patterns of live and dead material, thereby providing conditions for a broader array of flora and fauna in naturally regenerated stands or in pine plantations (Palik \& Zasada 2003).

\section{Implications for Practice}

- Given that the average snag density from our reference plots falls within the range from work in Minnesota, planners and managers should have considerable leeway in setting snag density objectives in mixed-pine forests of the Upper Midwest (i.e. 24-140 stems/ha).

- Snag composition should also be considered in management as snags of longer-lived species, such as red pine, may decay slower and thus be retained on site longer than snags of shorter-lived species (e.g. jack pine, aspen). Snag composition also is important as snags of some species (e.g. red pine) will often attain a greater size than snags of other species (e.g. jack pine).

- Variability in DC development among treatments and tree species suggests that forest managers should tailor snag prescriptions to provide a diversity of snag conditions over time.

\section{Acknowledgments}

Funding was provided by Seney NWR, the Seney Natural History Association, The Ohio State University, and the Joint Fire Science Program. H. Cornwall, J. Downs, D. Hunter, K. Leister, J. May, T. Macy, A. Neel, R. Plumb, J. Polasik, S. Rist, K. Trinkle, and H. Whitman assisted with data collection. L. Shartell assisted with data analysis, and the edits and comments of D. Kashian, two anonymous reviewers, and the associate editor greatly improved this article. The findings and conclusions in this article are those of the authors and do not necessarily represent the views of the U.S. Fish and Wildlife Service.

\section{LITERATURE CITED}

Aakala, T., S. Fraver, B. J. Palik, and A. W. D’Amato. 2012. Spatially random mortality in old-growth red pine forests of northern Minnesota. Canadian Journal of Forest Research 42:899-907.

Albert, D. A. 1995. Regional landscape ecosystems of Michigan, Minnesota and Wisconsin: a working map and classification. United States Department of Agriculture Forest Service General Technical Report, NC-178, St. Paul, Minnesota.

Angers, V. A., P. Drapeau, and Y. Bergeron. 2010. Snag degradation pathways of four North American boreal tree species. Forest Ecology and Management 259:246-256. 
Burger, T. L., and J. Kotar. 2003. A guide to forest communities and habitat types of Michigan. University of Wisconsin Press, Madison.

Corace, R. G. III, P. C. Goebel, D. M. Hix, T. Casselman, and N. E. Seefelt. 2009. Applying principles of ecological forestry at National Wildlife Refuges: experiences from Seney National Wildlife Refuge and Kirtland's Warbler Wildlife Management Area, USA. The Forestry Chronicle 85:1-7.

Corace, R. G. III, N. E. Seefelt, P. C. Goebel, and H. L. Shaw. 2010. Snag longevity and decay class development in a recent jack pine clearcut in Michigan. Northern Journal of Applied Forestry 27:125-131.

Corace, R. G. III, L. M. Shartell, L. A. Schulte, W. L. Brininger Jr., M. K. D. McDowell, and D. M. Kashian. 2012. An ecoregional context to forest management for National Wildlife Refuges of the Upper Midwest, USA. Environmental Management 49:359-371.

Drobyshev, I., P. C. Goebel, D. M. Hix, R. G. Corace III, and M. SemkoDuncan. 2008a. Pre- and post-European settlement fire history of red pine-dominated forest ecosystems of Seney National Wildlife Refuge, Upper Michigan. Canadian Journal of Forest Research 38:2497-2514.

Drobyshev, I., P. C. Goebel, D. M. Hix, R. G. Corace III, and M. SemkoDuncan. 2008b. Interactions between forest composition, structure, fuel loadings and fire history: a case study of red pine-dominated forests of Seney National Wildlife Refuge. Forest Ecology and Management 256: $1723-1733$.

Duvall, M. D., and D. F. Grigal. 1999. Effects of timber harvesting on coarse woody debris in red pine forests across the Lake States, U.S.A. Canadian Journal of Forest Research 29:1926-1934.

Franklin, J. F., H. H. Shugart, and M. E. Harmon. 1987. Tree death as an ecological process. Bioscience 37:550-556.

Franklin, J. F., R. J. Mitchell, B. J. Palik. 2007. Natural disturbance and stand development principles for ecological forestry. United States Department of Agriculture Forest Service General Technical Report, NRS-GTR-19, St. Paul, Minnesota.

Fraver, S., and B. J. Palik. 2012. Stand and cohort structure of old-growth Pinus resinosa-dominated forests of northern Minnesota, USA. Journal of Vegetation Science 23:249-259.

Frelich, L. E. 2002. Forest dynamics and disturbance regimes. Cambridge University Press, Cambridge, United Kingdom.

Fridman, J., and M. Walheim. 2000. Amount, structure, and dynamics of dead wood on managed forestland in Sweden. Forest Ecology and Management 131:23-36
Hansen, A. J., T. A. Spies, F. J. Swanson, and J. L. Ohmann. 1991. Conserving biodiversity in managed forests: lessons from natural forests. Bioscience 41:382-392.

Harmon, M. E., J. F. Franklin, F. J. Swanson, P. Sollins, S. V. Gregory, J. D. Lattin, et al. 1986. Ecology of coarse woody debris in temperate ecosystems. Advances in Ecological Research 15:133-302.

Hunter, M. L. Jr. 1990. Wildlife, forests, and forestry. Prentice-Hall, Inc., Englewood Cliffs, California.

Hutto, R. L. 2006. Toward meaningful snag-management guidelines for postfire salvage logging in North American conifer forests. Conservation Biology 20:984-993.

Luyssaert, S., E. D. Schulze, A. Borner, A. Knohl, D. Hessenmoller, B. E. Law, P. Ciais, and J. Grace. 2008. Old-growth forests as global carbon sinks. Nature 455:213-215.

McCune, B., and J. B. Grace. 2002. Analysis of Ecological Communities. MjM Software, Gleneden Beach, Oregon.

Meretsky, V. J., R. L. Fischman, J. R. Karr, D. A. Ashe, J. M. Scott, R. F. Noss, and R. L. Schroeder. 2006. New directions in conservation for the National Wildlife Refuge System. Bioscience 56:135-143.

Morrison, M. L., and M. G. Raphael. 1993. Modeling the dynamics of snags. Ecological Applications 3:322-330.

Palik, B. J., and J. C. Zasada. 2003. An ecological context for regenerating multi-cohort mixed-species red pine forests. United States Department of Agriculture Forest Service General Technical Report, NC-382, St. Paul, Minnesota.

Rist, S. G. 2008. Legacies of forest management and fire in mixed-pine forest ecosystems of the Seney National Wildlife Refuge, Eastern Upper Michigan Thesis. The Ohio State University, Columbus.

Seymour, R. S., and M. L. Hunter Jr. 1999. Principles of ecological forestry. in M. L. Hunter Jr., editor. Managing biodiversity in forest ecosystems. Cambridge University Press, Cambridge, United Kingdom.

Stearns, F., and G. E. Likens. 2002. One hundred years of recovery of a pine forest in northern Wisconsin. The American Midland Naturalist 148:2-19.

Stephens, S. L. 2004. Fuel loads, snag abundance, and snag recruitment in an unmanaged Jeffrey pine-mixed conifer forest in Northwestern Mexico. Forest Ecology and Management 199:103-113.

Youngman, J. A., and Z. G. Gayk. 2011. High density nesting of black-backed woodpeckers (Picoides arcticus) in a post-fire Great Lakes jack pine forest. The Wilson Journal of Ornithology 123:381-386. 